\title{
A Monoclonal Antibody Specific for the A Antigen of Brucella spp.
}

\author{
By ROSALIND QUINN, ${ }^{1}$ AILSA M. CAMPBELl ${ }^{1}$ and A. P. PHILlipS ${ }^{2 *}$ \\ ${ }^{1}$ Department of Biochemistry, University of Glasgow, Glasgow G12 $8 Q Q, U K$ \\ ${ }^{2}$ Chemical Defence Establishment, Porton Down, Salisbury, Wiltshire SP4 OJQ, UK
}

(Received 23 March 1984)

\begin{abstract}
Two murine monoclonal antibodies of the IgG3 class have been isolated after immunization with Brucella abortus. An indirect immunofluorescence test was used to screen hybridoma supernatants and subsequently to determine the cross-reactivity of the monoclonal antibodies with other bacteria. One monoclonal antibody reacted with all the smooth Brucella biotypes tried and with Yersinia enterocolitica serogroup $\mathrm{O}: 9$, though not with rough $B r$. ovis or with strains of Escherichia, Proteus, Salmonella, Pseudomonas, Francisella and Bordetella. The other monoclonal antibody displayed a high degree of specificity for brucellae carrying the A lipopolysaccharide-protein surface antigen. The implications for the diagnosis of brucellosis are discussed.
\end{abstract}

\section{INTRODUCTION}

The considerable antigenic overlap between individual Brucella spp. has hindered the development of antibody reagents able to identify Brucella organisms to species and, ultimately, biotype level. One cause of serological cross-reactions is believed to be the lipopolysaccharideprotein complex bearing the $\mathbf{A}$ and $\mathbf{M}$ antigens in proportions varying with the species and biotype; this complex is present on the cell surface of all smooth brucellae (Diaz et al., 1968a, b). The cross-reaction between Brucella spp. and Yersinia enterocolitica of serogroup O:9, first described by Ahvonen et al. (1969), has also been attributed to the $A+M$ antigenic complex (Diaz et al., 1970). However, Diaz \& Bosseray (1974) later suggested that antibodies against the polysaccharide B antigen were involved. Lipopolysaccharide somatic antigens are also implicated in the cross-reaction between Brucella spp. and Salmonella serotypes of KauffmannWhite group N (Cioglia, 1950; Corbel, 1975).

The involvement of cell surface antigens in the cross-reactions within the Brucella genus and also between brucellae on the one hand and yersiniae and salmonellae on the other, is likely to hinder the development of specific fluorescent antibody reagents at least as much as it has the development of agglutinins and precipitins (Raybould, 1982). Early attempts to produce fluorescent antibodies against brucella organisms resulted in conjugates that were genus- but not species-specific (Biegeleisen \& Moody, 1960). Corbel (1975) reported for a fluoresceinconjugated IgG to smooth $\mathrm{Br}$. abortus that attempts to remove the cross-reactions with $\mathrm{Br}$. melitensis, $B r$. suis and $Y$. enterocolitica $O: 9$ by selective absorption with these organisms resulted in loss of all conjugate activity against brucellae and yersiniae. In contrast, the antiserum from which this conjugate was derived gave appreciable titres of $B r$. abortus specific agglutinins after cross-absorption with $\mathrm{Br}$. melitensis. The fluorescent conjugate also stained group $\mathrm{N}$ salmonella organisms; but this reaction occurred only at low dilutions of conjugate, and could be removed by absorption with salmonella organisms without affecting the fluorescent staining of brucella or yersinia strains.

Monoclonal antibody technology (Kohler \& Milstein, 1975) makes the detailed analysis of type-specific and cross-reacting antigens among Brucella spp. a feasible aim. The dissection of

Abbreviations: FITC, fluorescein isothiocyanate; IF, immunofluorescence. 
the immune response in this manner can clearly lead to better understanding of the structure, localization and function of the antigen in different strains together with analysis of the crossreactions in the animal immune response. In the work described below two murine monoclonal antibodies raised against $\mathrm{Br}$. abortus were analysed for their cross-reactivity among different strains and biotypes of Brucella and among other bacteria using an indirect immunofluorescence (IF) assay.

\section{METHODS}

Antigens. Brucella, Yersinia and Salmonella strains of the stated biotype and serotype were kindly donated by $\mathrm{Dr}$ M. J. Corbel, of the MAFF Central Veterinary Laboratory, Weybridge, Surrey, UK. Salmonella strains, Escherichia coli $\mathrm{O} 157$ and Proteus vulgaris were grown overnight in nutrient broth at $37^{\circ} \mathrm{C}$, in shake flasks. Bordetella pertussis GL353 was grown as described by Morse \& Morse (1976). Other bacteria were grown in a Difco GC medium base containing $10 \%(v / v)$ horse serum (Wellcome, no. 3 ) at $37^{\circ} \mathrm{C}$ for $2 \mathrm{~d}$.

To inactivate bacteria, formaldehyde was added to $1 \%(w / v)$ and suspensions were incubated overnight at $37^{\circ} \mathrm{C}$. The bacteria were then washed six times in phosphate-buffered saline (PBS: $0.1 \mathrm{M}-\mathrm{NaCl}, 20 \mathrm{mM}$-sodium phosphate buffer pH 7.7), and were finally suspended in PBS made $0.1 \%$ with respect to formaldehyde. Total counts were performed by phase-contrast microscopy. Suspensions were then diluted to $10^{9}$ organisms $\mathrm{ml}^{-1}$ and were stored at $8-10^{\circ} \mathrm{C}$. Working dilutions of bacteria were prepared freshly each day.

Production of monoclonal antibodies. Balb/c mice were immunized intraperitoneally (i.p.) with $10^{8}$ Br. abortus 544 organisms in complete Freund's adjuvant, and again with $10^{7}$ organisms two weeks later. Four months after the original immunization and $4 \mathrm{~d}$ prior to fusion the mice were boosted with $10^{8}$ organisms in phosphate-buffered saline ( $\mathrm{PBS}^{*}: 0 \cdot 15 \mathrm{M}-\mathrm{NaCl}, 3 \mathrm{~mm}$-sodium phosphate buffer $\mathrm{pH} 7 \cdot 3$ ). Blood was collected and the 'hyperimmune' serum was separated and stored at $-20^{\circ} \mathrm{C}$. The spleen cells from the immunized animals were fused at a ratio of $4: 1$ with P3-X63/Ag 8.653 mouse myeloma cells (Flow Laboratories) at $84 \%$ viability and in exponential growth. Hybrid cells were seeded at $10^{6}$ cells per well in 24-well Costar plates in RPMI medium (Flow Laboratories) containing $20 \%(\mathrm{v} / \mathrm{v})$ foetal calf serum (Northumbria Biologicals) supplemented with penicillin and streptomycin. Clones positive by immunofluorescence (IF) were selected and subcloned $35 \mathrm{~d}$ later. Clones $1 \mathrm{~B} 3$ and $2 \mathrm{Cl}$ continued to secrete antibody after two subclonings at one cell per well on mouse spleen cell feeders in 96-well Costar plates and were selected for further analysis and expanded into 24-well Costar plates. Supernatants were stored at $-20^{\circ} \mathrm{C}$.

Ascitic fluid was produced from the $2 \mathrm{Cl}$ clones. A Balb/c mouse was primed with an i.p. injection of $0.4 \mathrm{ml}$ pristane (2,6,10,14-tetramethylpentadecane: Aldrich). After an interval of $10 \mathrm{~d}$, the mouse received an i.p. injection of approximately $10^{6}$ viable $2 \mathrm{Cl}$ hybridoma cells in $0.3 \mathrm{ml}$ sterile $\mathrm{PBS}^{*}$. Five weeks later ascitic fluid was tapped from the peritoneum using a $21 \mathrm{G}-1 \cdot 5^{\prime \prime}$ needle. Three further taps were removed at 2 -d intervals. The ascitic fluid was centrifuged at $10000 \mathrm{~g}$ for $1 \mathrm{~min}$; the supernatant was stored at $-20^{\circ} \mathrm{C}$.

IF screening of hybridoma supernatants. Supernatants were assayed for anti-Br. abortus activity by indirect IF. $10^{4} \mathrm{Br}$. abortus 544 organisms diluted from stock in distilled water were applied in $10 \mu \mathrm{l}$ aliquots to multispot microscope slides [C. A. Hendley (Essex) Ltd] and dried at $65^{\circ} \mathrm{C}$ for $20 \mathrm{~min}$. The slides were fixed in acetone and stored. A $10 \mu \mathrm{l}$ sample of the hybridoma supernatant to be tested was then added to each spot and the slides were incubated at room temperature overnight in a humidified chamber. The samples were removed with a Pasteur pipette and the slides were washed three times in $0.2 \mathrm{M}-\mathrm{Tris} / \mathrm{HCl}, 0.2 \mathrm{M}-\mathrm{NaCl}, 0.05 \%$ Tween $20 \mathrm{pH} 7.4$ (TNT), once in $0.2 \mathrm{M}$-Tris $/ \mathrm{HCl}, 0.2 \mathrm{M}-\mathrm{NaCl} \mathrm{pH} 7.4(\mathrm{TN})$ and once in distilled water, and were air dried. Then $5 \mu \mathrm{l} \mathrm{FITC-}$ conjugated sheep anti-mouse IgG, prepared essentially as earlier described for sheep anti-rabbit IgG (Phillips \& Martin, $1982 a, b)$, was added to each well at a concentration of $100 \mu \mathrm{g} \mathrm{ml}^{-1}$ in normal serum buffer $[1 / 6(\mathrm{v} / \mathrm{v})$ normal goat serum, $0 \cdot 1 \%(\mathrm{w} / \mathrm{v})$ Brij $35(\mathrm{BDH})$ in PBS]. The slides were incubated in a humidified chamber for $1 \mathrm{~h}$ in the dark, then washed as before, dried and mounted in $10 \mathrm{mM}$-sodium bicarbonate buffer $\mathrm{pH} 8 \cdot 2,90 \%(\mathrm{v} / \mathrm{v})$ glycerol for microscopy.

Negative (autofluorescence) controls were performed by substituting $1: 100$ normal mouse serum for the hybridoma supernatant. Positive controls were performed by substituting hyperimmune mouse serum at a dilution of $1: 500$.

IF testing for specificity. An indirect IF test was performed essentially as described above, but with the following modifications. $5 \times 10^{4}$ Brucella organisms or other test bacteria were dried on each well of the multispot slides, at $60^{\circ} \mathrm{C}$. The slides were fixed in ethanol. A $5 \mu \mathrm{l} \mathrm{sample} \mathrm{of} \mathrm{supernatant,} \mathrm{or} \mathrm{ascites} \mathrm{fluid,} \mathrm{or} \mathrm{hyperimmune} \mathrm{mouse}$ serum, diluted as specified in normal serum buffer, was added to the wells and incubated for $30 \mathrm{~min}$. For autofluorescence controls, normal serum buffer was used alone. The slides were then washed three times in $0.1 \%$ Brij PBS and once in distilled water. The wells were then incubated with the FITC-conjugated sheep anti-mouse IgG for $30 \mathrm{~min}$. After washing, the slides were mounted in the bleach retardant glycerol-based mountant Citifluor (Chemistry Department, The City University, London, UK). 
Microscopy was performed using a Leitz fluorescence microscope (Dialux 20 fitted with a Ploemopak 2.4) at a magnification of $\times 1000$; fluorescence intensity of bacteria was scored subjectively on a scale from 0 (autofluorescence) to $t++$.

Determination of antibody class. Antibody class was determined by ELISA (enzyme-linked immunosorbent assay) in a 96-well microtitre plate (Falcon). $10^{6} \mathrm{Br}$. abortus 544 organisms were applied to each well in $50 \mu \mathrm{l}$ buffer and dried in a $65^{\circ} \mathrm{C}$ oven. The cells were then fixed with methanol and dried. A $100 \mu$ sample of hybridoma supernatant was added to each well, and incubated at room temperature for $45 \mathrm{~min}$. The wells were then washed once in TN, three times in TNT, once in TN, and once in distilled water, and were shaken dry. Then $100 \mu 1$ rabbit anti-mouse class-specific antibody (Miles) was added to each well at a starting dilution of $1: 100 \mathrm{in} 0.9 \%$ (w/v) $\mathrm{NaCl}$ containing 1:4 sheep normal serum, with doubling dilutions across the microtitre plate. The class-specific antibodies used were anti-IgG1, anti-IgG2A, anti-IgG2B, anti-IgG3, anti-kappa chain and anti-lambda chain. After incubating for $30 \mathrm{~min}$ and washing as before, sheep anti-rabbit horseradish peroxidase antibody (Miles) was applied at a dilution of $1: 1000$, and incubated for $30 \mathrm{~min}$. The colour was then developed with $o$-phenylenediamine (BDH) at a concentration of $0.4 \mathrm{mg} \mathrm{ml}^{-1}$ in the presence of $0.01 \%(\mathrm{v} / \mathrm{v})$ hydrogen peroxide. The absorbance of the supernatants at $492 \mathrm{~nm}$ was measured on a Titretek Multiskan Spectrophotometer.

\section{RESULTS}

In Table 1 the reaction of the monoclonal antibodies $1 \mathrm{~B} 3$ and $2 \mathrm{C} 1$ with a range of Brucella strains and the $Y$. enterocolitica serogroup $\mathrm{O}: 9$ is compared with the reactivity of the hyperimmune mouse serum in the indirect IF test. Clearly, 1B3 exhibited a specificity as broad as that of the hyperimmune serum, reacting with all the smooth Brucella strains and with Y. enterocolitica but not with rough $\mathrm{Br}$. ovis. In contrast, the $2 \mathrm{Cl}$ monoclonal antibody only reacted with Brucella biotypes believed to carry the A cell surface antigen; it did not react with $Y$. enterocolitica serogroup $\mathrm{O}: 9$. When a dilution series of the $2 \mathrm{Cl}$ ascites preparation was assayed, the reaction with $B r$. abortus biotype 7 and with $B r$. suis biotype 1 disappeared at lower dilutions than did the reactions with the other $\mathrm{A}^{+}$Brucella strains. Results at two dilution points are shown in Table 1. Neither the hyperimmune serum nor these monoclonal antibodies reacted with the following bacteria: Salmonella morehead, Salmonella $\mathrm{Br} 1443$, Salmonella $\mathrm{Br} 1775, S$. serenga, S. urbana, S. landau, Escherichia coli O157, Pseudomonas aeruginosa, Ps. multophilia, Proteus vulgaris, Francisella tularensis HN63 and Bordetella pertussis GL353.

When the immunoglobulin class of the 1B3 and 2C1 monoclonal preparations was investigated, both were found to possess an IgG3 heavy chain and kappa light chains.

Table 1. Specificity of mouse hyperimmune serum and monoclonal antibodies by IF

\begin{tabular}{|c|c|c|c|c|c|c|c|}
\hline & & & & Score & n IF test & & \\
\hline Organis & & & & & & $2 \mathrm{C} 1$ as & cites at \\
\hline Strain & Biotype & $\begin{array}{l}\text { A and } M \\
\text { antigens }\end{array}$ & $\begin{array}{l}\text { Hyperimmune } \\
\text { serum }\end{array}$ & $\begin{array}{c}\text { Supernatant } \\
\text { 1B3 }\end{array}$ & $\begin{array}{c}\text { Supernatant } \\
2 \mathrm{Cl}\end{array}$ & $\overparen{1: 50}$ & $1: 200$ \\
\hline Br. abortus 544 & 1 & $\mathbf{A}^{+} \mathbf{M}^{-}$ & +++ & $+t+$ & $+t+$ & $+t+$ & +++ \\
\hline Br. abortus B3196 & 5 & $\mathbf{A}^{-} \mathbf{M}^{+}$ & +++ & +++ & 0 & 0 & 0 \\
\hline Br. abortus NCTC 10506 & 7 & $\mathbf{A}^{+} \mathbf{M}^{+}$ & +++ & +++ & +++ & ++ & + \\
\hline Br. melitensis $16 \mathrm{M}$ & 1 & $\mathbf{A}-\mathbf{M}^{+}$ & $+t+$ & +++ & 0 & 0 & 0 \\
\hline Br. melitensis $\mathrm{H} 38$ & 1 & $\mathbf{A}^{-} \mathbf{M}^{+}$ & ++ & +++ & 0 & 0 & 0 \\
\hline Br. suis 1330 & 1 & $\mathbf{A}^{+} \mathbf{M}^{-}$ & +++ & ++ & ++ & + & 0 \\
\hline Br. suis Thomsen & 2 & $\mathrm{~A}^{+} \mathbf{M}^{-}$ & +++ & +++ & +++ & +++ & +++ \\
\hline Br. suis 686 & 3 & $\mathbf{A}^{+} \mathbf{M}^{-}$ & +++ & ++ & +++ & +++ & +++ \\
\hline Br. neotomae NCTC 10084 & & $\mathrm{~A}^{+} \mathrm{M}^{-}$ & +++ & +++ & ++ & +++ & +++ \\
\hline Br. ovis $63 / 290$ & & $A^{-} \mathbf{M}^{-}$ & 0 & 0 & 0 & 0 & 0 \\
\hline Y. enterocolitica $296 / 68$ & $0: 9$ & & ++ & ++ & 0 & 0 & 0 \\
\hline
\end{tabular}

* See Brinley-Morgan \& McCullough (1974). 


\section{DISCUSSION}

The isolation of a monoclonal antibody $(2 \mathrm{Cl})$ that has a high degree of specificity for $\mathrm{A}^{+}$ Brucella strains and yet is unreactive with $Y$. enterocolitica $\mathrm{O}: 9$ should be of some importance to laboratories concerned with the study and control of brucellosis. An epitope of the A antigen of the brucella surface lipopolysaccharide-protein complex is likely to be involved. On the one hand, highly specific monoclonal antibodies could be used to prepare more selective antigens as vaccines or for use in agglutination and precipitin tests of serological activity. Equally, such monoclonal reagents are likely to find direct application in the tests used in serological assays. Thus, monoclonal antibodies may be of use either for blocking antigens or as competitive inhibitors in assays for circulating antibody activity.

The advantages of IF over agglutination tests for detecting brucella organisms in clinical and animal samples, in terms of speed and of minimum numbers of bacteria detectable, have already been described (Moody et al., 1961; Biegeleisen et al., 1962). The rapidity of the indirect IF also gives it an advantage over agglutination for measuring anti-brucella antibody, although lower antibody titres are obtained using IF (Biegeleisen et al., 1962). In view of the potential of IF methodology, the brief survey of the activity of mouse hyperimmune serum with non-brucella bacteria in the indirect IF test was performed early in this study. The cross-reaction results were similar to those previously reported for IF tests based on rabbit antibodies (Biegeleisen \& Moody, 1960; Corbel, 1973; Corbel \& Day, 1973; Corbel, 1975). Thus, it was concluded that the major disadvantage of using the mouse hyperimmune reagent for IF would be the cross-reaction with $Y$. enterocolitica O:9 and the lack of species specificity within the Brucella genus. In striving to produce monoclonal antibodies that would provide additional specificity in IF tests, an indirect IF technique was used to screen hybridoma supernatants, rather than one of the more usual ELISA techniques, in order to select directly for antibodies active against cell-surface antigens. This preliminary assessment of the specificity of the $2 \mathrm{Cl}$ monoclonal antibody for the A antigen serves to justify this experimental approach.

It is interesting to note that both antibodies produced are of the IgG3 subclass. This is a minor subclass of antibody in the mouse. A further monoclonal antibody from the same experiment proved to be of the IgM class but no antibodies of any other IgG subclass were detected. While clearly a larger panel of antibodies would need to be generated to form any firm conclusions, it is tempting to speculate that there may be an isotype preference for this particular antigen. The IgM antibodies are to be expected from any fusion experiment since some of the lymphocytes will not yet have undergone heavy chain switching, but two IgG3 antibodies are a comparatively rare phenomenon.

We are grateful to Dr R. G. Drake and Dr M. J. Corbel for advice, and to Miss Kay Wheeler for the excellent contribution during part of the industrial training year of her degree course.

\section{REFERENCES}

Ahvonen, P., Jansson, E. \& AHo, K. (1969). Marked cross-agglutination between Brucellae and a sub-type of Yersinia enterocolitica. Acta pathologica et microbiologica scandinavica 75, 291-295.

Biegeleisen, J. Z. \& Moody, M. D. (1960). Genus specificity of fluorescein-labelled anti-Brucella melitensis globulin. Bacteriological Proceedings, 140-141.

Biegeleisen, J. Z., Bradshaw, B. R. \& Moody, M. D. (1962). Demonstration of Brucella antibodies in human serum. Journal of Immunology 88, 109-112.

Brinley-Morgan, W. J. \& McCullough, N. B. (1974). Genus Brucella Meyer and Shaw 1920, 173. In Bergey's Manual of Determinative Bacteriology, 8th edn, pp. 278-282. Edited by R. E. Buchanan \& N. E. Gibbons. Baltimore: Williams \& Wilkins.

Croglia, L. (1950). Antigeni communi a brucelle e salmonelle. Giornale di batteriologia e immunologia 42, 81-90.
CORBEL, M. J. (1973). The direct fluorescent antibody test for detection of Brucella abortus in bovine abortion material. Journal of Hygiene 71, 123-129.

Corbel, M. J. (1975). The serological relationship between Brucella spp., Yersinia enterocolitica serotype IX and Salmonella serotypes of KauffmannWhite group $\mathbf{N}$. Journal of Hygiene 75, 151-171.

Corbel, M. J. \& DAY, C. A. (1973). Assessment of fluorescent antibody absorption procedures for differentiation of the serological response to Yersinia enterocolitica serotype IX and Brucella abortus in cattle. British Veterinary Journal 129, lxvii-lxxi.

Diaz, R. \& Bosseray, N. (1974). Estudio de las relaciones antigénicas entre $Y$. enterocolitica serotipo 9 y otras especias bacterianas gram-negatives. Microbiologia española 27, 1-14.

Duz, R., Jones, L. M. \& Wilson, J. B. (1968a). Antigenic relationship of the Gram negative organ- 
ism causing canine abortion to smooth and rough brucellae. Journal of Bacteriology 95, 618-624.

Diaz, R., Jones, L. M., Leong, D. \& Wilson, J. B. $(1968 b)$. Surface antigens of smooth brucellae. Journal of Bacteriology 96, 893-901.

Diaz, R., Lacalle, R., Medrano, P. \& Leong, D. (1970). Immunobiological activities of the endotoxin of Yersinia enterocolitica, type MY79. Proceedings of the Vth International Congress on Infectious Diseases, Vienna; bacteria 2, 11-17.

KoHLER, G. \& Milstein, C. (1975). Continuous cultures of fused cells secreting antibody of predefined specificity. Nature, London 296, 495-497.

Moody, M. D., Biegeleisen, J. Z. \& TAylor, G. C. (1961). Detection of brucellae and their antibodies by fluorescent antibody and agglutination tests. Journal of Bacteriology 81, 990-995.
MORSE, S. I. \& MORSE, J. H. (1976). Isolation and properties of the leucocytosis and lymphocytosis promoting factor of Bordetella pertussis. Journal of Experimental Medicine 143, 1483-1502.

Phillips, A. P. \& Martin, K. L. (1982a). Evaluation of a microfluorometer in immunofluorescence assays of individual spores of Bacillus anthracis and Bacillus cereus. Journal of Immunological Methods 49, 271282.

Phillips, A. P. \& Martin, K. L. (1982b). Assessment of immunofluoresence measurements of individual bacteria in direct and indirect assays for Bacillus anthracis and Bacillus cereus spores. Journal of Applied Bacteriology 53, 223-231.

RAYBould, T. J. G. (1982). Antigens of diagnostic significance in Brucella abortus. Canadian Journal of Microbiology 28, 557-566. 